\title{
A Proposed Model in Fundamental of Decision Making Process at Local Government Level
}

\author{
Kamarudin Ngah ${ }^{1}$, Zaherawati Zakaria ${ }^{2}$, Zaliha Hj Hussin ${ }^{2}$, Nazni Noordin ${ }^{2}$, Jamaludin Mustaffa $^{3}$ \& Mohd Zool \\ Hilmie Mohamed Sawal ${ }^{4}$ \\ ${ }^{1}$ Pusat Penyelidikan Dasar dan Kajian Antarabangsa (CenPRIS), Universiti Sains Malaysia (USM), Pulau \\ Pinang, Malaysia \\ ${ }^{2}$ Faculty of Administrative Science \& Policy Studies, Universiti Teknologi MARA, Merbok, Malaysia \\ ${ }^{3}$ College of Arts and Science, Universiti Utara Malaysia, Sintok, Malaysia \\ ${ }^{4}$ Faculty of Information Management, Universiti Teknologi MARA, Merbok, Malaysia
}

Correspondence: Zaherawati Zakaria, Faculty of Administrative Science \& Policy Studies, Universiti Teknologi MARA, P. O Box 187, 08400 Merbok, Kedah, Malaysia. Tel: 60-4-456-2565. E-mail: zaherawati@kedah.uitm.edu.my

\author{
Received: April 1, $2012 \quad$ Accepted: April 29, $2012 \quad$ Published: July 1, 2012 \\ doi:10.5539/ass.v8n8p96 URL: http://dx.doi.org/10.5539/ass.v8n8p96
}

\begin{abstract}
Currently we are witnessing significant changes in the nature of policy making and management in local government. Essentially, these changes represent a move away from the relatively passive approach towards a more purposeful approach in which local authorities attempt to learn about the nature and causes of local problems and to respond accordingly. Therefore, what is required is a theoretical framework that could explain and relates the concept of planning to the concept of power, and seeks an explanation of decision-making process. The organizational changes and complex interaction in local government that involve politicians, planners, officers and decision-making bring about the important of current practices and evaluating future changes. Thus, this article tries to propose a model of decision making-process for greater performance in local government. In the findings, there are a few factors influencing councilors in running their functions. It shows that councillor as representatives at local government level will be a good policy maker in handling local manners by adopting this proposed model. In future research, to be a greater practice of rational decision making, perhaps the stakeholders such as households, business communities, community leaders and Non-Governmental Organizations (NGOs) will be collaborated effectively with councillor in decision making-process relates to local affairs.
\end{abstract}

Keywords: local government, decision making, process, representation, councillor

\section{Introduction}

Local government can be defined in terms of wider political values, by referring to the dispersal of power from the centre to the localities. Sharpe (1979) has criticized this view on the ground that local authorities are not immune from arbitrary tendencies. One of the claimed is precisely that services may be varied to suit conditions in different localities. But local government may enhance equally by providing access to political activity for wider groups of people that are accommodated through national politics. Cox and Morgan (1973) define a political system as 'a set of structures and processes, the core of which is an authoritative centre of decision-making'. Local authorities possess in the full council meeting a 'centre of decision-making', they do not control all public policy decisions within the geographical area in which they operate. Many decisions are taken by local and regional offices of national government departments and other agencies.

However practical decision-making and theoretical approaches have both found difficulties in confining themselves to narrow definitions of the problem. Attempts to tackle the difficulties manifesting themselves in the inner cities in the localized areas in which they are most acute have only revealed the inadequacy of such approaches (Edwards, 1980; Higgins et al, 1983). Nowadays, the problems of the inner cities are understood related to wider changes in the economic and social structure, and need to be tackled through this context. 
The number, identity, and placement of the decision makers are another crucial factor in decision-making process. Rational decision making assumes that one or a very few persons make the choices, with no distraction or dissent from outside sources. "However, the most decisions are made in situations where many share power. Incrementalism is uniquely suited to pluralistic, competitive politics, in which interpersonal agreement is integral to basic decisions and every participant claims some part in the action.” (William, 1996).

\section{Literature Review}

Three basic types of formal procedure decisions rule by which public administrations can operate, are identified. They are bureaucracy, purposive action and public control. Bureaucratic organization is most frequently portrayed as a hierarchy of super ordination and subordination based on authority. Activities, authority and duties within the organization are ordered by rules of procedure which are abstract, consistent, stable and exhaustive. In this way the legitimacy, fair dealing and efficiency of the organization are ensured. The individual working within a bureaucratic framework is subject to this impersonal order by strict and systematic control. Officials apply general rules to particular cases without prejudice or malice and are appointed on the basis of technical qualifications and the skills needed for specific tasks and levels within the bureau.

Purposive action as a second mode of decision-making takes its characteristics and inspiration from the principle of technical rationality. Technocratic procedures are substituted for bureaucratic rules. This mode of policy-making is well known under the title of rationalistic planning. The greatest stricture against the application of technical-rational approaches to social problem is goal definition. Purposive procedures may be effective in meeting the closely defined objectives of the industrial/commercial enterprise but goals are so easily bracketed and taken for granted in dealing with broader, less circumscribed problems.

This states that in any situation an administrator ought ideally to examine all possible courses of action open to him, trace through the consequences of each alternative. He should then choose that course of action which is expected to provide the greatest net satisfaction. The basic of rational problem-solving process is the economic assumption that people attempt to maximize their outcomes when they make choices. Theoretically, people select a criterion, such as income or profit, then evaluate all decision alternatives in terms of that criterion, and finally select the alternative that will produce the best results (Peter, 1972; Robert \& Janet, 2006).

The rational model is often cited as the 'ideal' way to make decisions, especially those involving major public policies. Specifically, the model breaks decision making down into several phases (Jeffrey, 2005):

1) Establish a complete set of operational goals with relative weights allocated in different degrees to which each may be achieved.

2) Establish a complete inventory of other values and resources with other weights.

3) Prepare a complete set of the alternative decisions that will resolve the problem.

4) Prepare a complete set of valid predictions of the cost and benefits of each alternative, including the extent to which each alternative will achieve the various operational goals, consume resources, and realize or impair other values.

5) Calculate the net expectations for each alternative by multiplying the probability of each benefit and cost for each alternative by the utility of each, and calculate the net benefit (or cost) in utility unit.

6) Compare the net expectations and identify the alternative (or alternatives if two or more are equally as good) with the highest net expectations.

Stated more simply, the rational model (sometimes called the rational-comprehensive model) merely means defining one's goals, analyzing the available alternatives, and selecting the alternative that best meets the goals. Reflecting on Simon's work, one is inclined to conclude that it would be more profitable to investigate administrative behaviour directly, rather than as departures from some idealized model of decision-making. On the other hands, a study of decision models can be helpful in three other ways.

Decision-making in local government addresses itself in particular to those more strategic levels of choice which tend to be linked with the terms 'planning' and 'policy-making', and to impinge on the future physical and social development of local communities in a variety of ways which may be only imperfectly understood. Any organization tends to develop certain methods to assist it in taking decisions which, even if they are ill formulated, can be thought of collectively as forming a 'technology of choice'. The planning process in local government requires a technology of choice that explicitly recognizes the particular types of challenge posed at this level. These include the difficulty of isolating one decision from another. The difficulty of appreciating what range of solutions may be possible, the difficulty of making value judgments when confronted with a wide range of social 
effects, and the difficulty of striking a balance between the pressures for early commitment and the flexibility to adapt to unforeseen circumstances. If such a technology is to be consistent with the principle of democratic control, new approaches will be necessary of internal organization and communication within local authorities (Friend \& Jessop, 1971).

Therefore, any form of planning activity by a local authority must take place within a procedural setting which is laid down in the standing orders of council and in more specific instructions to individual committees. The formal sequence of steps in the decision-making process in any local authority in the United Kingdom can be summarized in three different stages; departmental processes, committee processes, and council processes. In some cases, the formal processes of decision may become more complicated because of the involvement of more than one department or a requirement for formal approval of a proposal by more than one committee. If the committee fails to reach decision, two possibilities could occur. That the matter may be referred to a senior committee because it raises issues which the committee does not feel competent to settle on its own, or that it may be referred back to the chief officer to be raised again at a later meeting after further assessments within his department. Assuming that a decision is eventually reached, either by committee in question or by a senior committee, the decision will then be minuted and submitted to the full council at its next meeting for endorsement by a majority vote of council members or - in the case of a decision taken under delegated powers where council endorsement is necessary - to give other members of council an opportunity to ask any questions about the matter concerned.

In local government, the committee meeting is the only official occasion at which officers and elected members meet together, and in this stage the recommendations of the officers-if acceptable-become translated into formal decisions of the members. However, despite the formal significance of the occasion, it was evident to us that, particularly where the more strategic decisions were concerned, the committee meeting tended to play a strictly limited role in the actual processes of decision-'making', which extended well beyond the formal procedure of decision- 'taking' enshrined in standing orders (Friend \& Jessop, 1971).

These limitations to the effectives of the committee as a decision-making body meant that the reality of the decision-making process tended to become largely concentrated within the departmental offices, with the chairman being consulted on any issues seen by the chief officer to have political implications, and any particularly contentious matters being brought in advance to the full majority party group. This tendency to develop channels other than that of the committee meeting for the discussion of major strategic issues did not. However, that means the value of the committee meeting itself, had become negligible.

\section{Methods and Materials}

Besides exploring the fundamental concepts, theories and models of decision-making process as the main objective of the first stage of the study process, as the second part of the study, do examine the findings based on the in-depth interviews with Councillors of Kuantan Municipality Council. The findings presented are derived from those meeting and support by input from other parties such as politicians, planners and academicians. The interpretation of Councillor's respond to certain questions were descriptively analyses and compared to what have been found in the quiet similar studies conducted in several local government, especially in United Kingdom, either theoretically or through a specific case study. The formal and informal discussions were applied to gather information on the current practices. The main objective through this exercise is to determine what factors contributed or influence councillors during the decision-making process. These factors will be formulated towards a new set of theoretical or conceptual framework that needs to be tested or predicted. In this case, in-depth interview were carried out with six Councillors of Kuantan Municipal Council (MPK) as well as informal discussion with politicians, academicians and local government's administrators.

\section{Findings}

\subsection{Councillor's Profile}

Before attempting to answer the research question in this study, descriptive analysis on Councillor's profile was made. Four of the Councillors reported to be in the business profession. The other two were reported to be a teacher and a full time politician, accordingly. Most of the Councillors hold either diploma or degree as their highest educational achievement, and served more than three years as a Councillor. It is interesting to notes that all of them hold the highest ranking post in the political parties, either at the division level or the state level, for at least more than three years. In general, the profiles reflected the acceptable level of qualification of Councillors that been imposed as one of the condition for the appointment. This profile's observation also implies what Hampton (1970) described, based on his research in Sheffield, that a Councillor needs to have no relationship, other than a questionable loyalty, with the ward or divisions they represents. As it is political label rather than the candidate's local profile that is instrumental in securing electoral success, it follows that loyalty is to the party and, more 
importantly, to the party group. At least in urban areas, it is only after election that the Councillor may develop a local profile and area loyalty. Such loyalty may, however, be severely tested if a divergence of opinion occurs between the group and party and the local electorate over any local event, or over the general conduct of council affairs.

\subsection{The Process of Decision-Making}

One of the primary investigations of this study is to explore the complexity of the decision-making process at the local government level. It is important to understand how the decisions are made and the various levels of decision-making involved. The Malaysia Local Government Act 1976 (Act 171) provides for decision to be made at council meeting, attending by at least one-half of the full number of Councillors that chaired by the Mayor or President (Yang DiPertua), and the full number of Councillors for special meeting and one-third for ordinary (committee) meeting.

The study indicates that most Councillors perceived the decision-making is a complex process, by referring to the second and third level of formal sequences of steps in the decision-making process. This steps in the decision-making process in Kuantan Municipality Council is similar to that in any other local authorities in the country, as what have been practices in the United Kingdom. Many of the routine decisions fall within the discretion of the director of a department or his subordinates. In some cases, the formal process of decision-making became more complicated due to the involvement of various inter-departmental inputs as well as other external agencies or parties. The committee may unable to reach any decision or majority of Councillors may disagree with the decision that needs to be endorsed.

As a community representative, it is the duty of Councillor to listen to the constituents and at the same time they need to act accordingly in determine any council's matter. The Councillors must use their own judgment in evaluating an issue and look at the issue in a holistic manner before made any decision. They are expected to be able to balance the community interests with other matters, while remaining within the constraints of planning law (Nikmatul, 2011). The system of decision-making at this local government level, especially at the second level is more complex, involves the participation of many different individuals and parties. It was here that new members were brought face to face with the difficulty of sharing limited resources between many community needs, and with the various forms of constraint imposed by central and state government.

\subsection{Factors Influencing Decision-Making}

The results of what Councillors thought the most important factors influence their decision-making throw some light on the issues central to understanding the dynamics of political preference in the process. Four factors indicate Councillor's preference, namely:

1) The interest of the public/tax payers.

2) The interest of state government

3) The interest of the party

4) Economic and infrastructure development

From the list, it can be summed up that most Councillors realize that their actions should not be contradictory and against the policies decided upon by the state or interest of the party and the people. At the same time they carry the responsibilities to draw the policy to determine the direction of the local council and the direction has to augur well with the state policy and meet the people's expectations.

The similar approaches has been conducted by Young \& Rao (1995) for Widdicombe Committee, United Kingdom, in identified what was the Councillor focus of representation, from the point of view of the public (respondents). Do electors expect their Councillors to act as party loyalists or do they perceive the Councillors as having a more direct relationship with his or her electoral area? Electors' expectations of their Councillors are inescapably conditioned by the prominence in local government elections and local politics of national party politics. Equally important are electors' attitudes towards the balance needed between a Councillor's own personal views, those of his or her party and those of the people he or she represents (Copus, 2004). Young and Rao conclude that in a system dominated by the party group: 'there is an overwhelming expectation that Councillors should place local interests-either at ward level or across the local area-first. And there is also a clear indication that the public thinks there are limits to the role of party politics (Young \& Rao, 1995). As the link between the party and Councillor is stronger than that between the Councillor and the electorate, the Councillor will act as a trustee when it comes to developing a representative relationship with citizens, but will act as a delegate when it comes to his or her relationship with the party or the party group. 
In addition to the above factors, Councillors still perceived that laws and regulations (including state structure plan and local plan) acts as an important means to guide them in the decision-making process. A local plan is a statutory plan which is a legal document that must be followed religiously by all parties including the government (Goh, 2008).

Development regulations are among the most powerful forces shaping the built environment. Land use laws have an enormous effect on urban design solutions. Environmental regulations also affect location decisions, prohibiting the construction of buildings and roads in vulnerable places and shaping conservation lands.

\subsection{Factors Contribute to Decision-Making and Preferences}

This is the main objective of the study. The four factors, as described has been developed and expanded based on the literature reviews and discussions with some politicians, planners, academicians, as well as Councillors. As a result, 13 factors have been identified in order to assist the Councillors to make a right decision on any matters related to council's affairs. These factors were categorized under (Friend \& Jessop, 1971);

1) administrators and operational policies

2) local objectives

3) external constraints

Friend \& Jessop (1971) state that whenever a situation cannot easily be related to existing operational policies, then the choice of a response may be shaped partly by the personal and group objectives of those concerned, and partly by their appreciation of the constraints which may inhibit the attainment of those objective: such constraints may apply in particular to their ability to mobilize the resources for certain desired courses of action. All these factors-the operational policies themselves, the local objectives, and the appreciation of external constraints-contribute towards the general view of the way in which appropriate actions should be selected.

The factors referred as a standard preference for Councillors while debating or throwing any ideas during the council's meeting, especially at the second and the third levels of the decision-making process. The formulation of a new model in decision-making process at the local government level will be based on this assumption. The 13 factors include:

1) The interest of the party

2) The interest of the council

3) The personal interest

4) The expectation of tax payers

5) In parallel to the federal government policies

6) In parallel to the state government policies

7) Support the strategic planning of the council

8) The image of the town center

9) The impact on environment

10) The socio-economic impacts

11) The physical impacts

12) The flow of information

13) The new knowledge/ideas

In the second stage of the interview, this new model that based on 13 factors has been applied on the same Councillors. The result showed that all the Councillors feel that they had a clear guideline as compared to before that acts as a conceptual framework in assisting them in making the decision. At the same time these factors perceived as a check lists in ensuring no view of considerations will left behind during the decision-making process. The final research question is concerned on putting these factors in form of ranking. Councillors were asked to rank six factors that they think most important in influencing their decision. The result is diagrammatically shown, according to the priorities as stated by Councillors.

The finding indicates that the first top two factors fall under the category of local objectives, whereas the third and forth factors fall under the operational policies. Finally, the last two important factors fall under the external constraints. In responds to the question forwards by Copus (2004) on 'what drives Councillors to focus on either their relationship with the ward or division before all else, or to focus on the party group and its broad 
policy-making and governing role?'. The answer is clearly defined by the above finding. However the problem of expressing preferences becomes difficult to tackle in circumstances where several alternative solutions are possible, where effects may be difficult to identify or to measure, or where there is no obvious single criterion for measuring their relative value (Friend \& Jessop, 1971).

Copus (2004) explored the concept of representative 'focus' that is where the representative will concentrate his or her attention when it comes to the political processes. Eulau et al. show that representatives will focus their attention on the needs of 'a geographical unit, a party, a pressure group or an administrative organization'. Jones (1973) noted that, as well as representing a 'geographical' area, the Councillor may also act as a representative of a broad section of the community, a particular organised group, another local authority or individual citizens. Heclo (1969) saw the Councillor as focusing their activity as a committee member, specialising on the business of the council, a constituency representative focusing on local concerns, or a party activist who approaches the work of the council and representation with the interests of the party at the forefront.

\section{Discussion \& Recommendations}

\subsection{Enhancing the Role of Councillors}

Councillors need to conceptually elevate themselves above 'what' and 'how' they serve for the people, or delegates, into a broader governing perspective, as, without that, they have little to distinguish themselves from ordinary citizens. Councillor's position is weakened perceptibly when it comes to dealing with officers, other public and private agencies and the government itself if they cannot act based on notions of having a governing mandate, rather than simply being to fulfill the interests of the constituency they represent, the interest of their party's view or the interest of the council's that they serve. In this case Councillors should act as a champion; championing the needs of a constituent and acting as an advocate of communities from within is a role more readily acceptable to.

Altering the relationship Councillors have with the council and the citizen of local communities, means altering the relationship they have with their party and party groups. It requires serious questioning of the nature of local representative democracy and the role played within it by political parties and party people. Further, as stated by Copus (2004), changing the nature of the representative relationship demands far more than exhortations to Councillors that they must base themselves more firmly within a ward and must grant the communities within it equality with, or even primacy over, the council as an institution and by implication the party group. By playing the role as community advocate, Councillors will ensure looking inwards to the needs of micro-managing the party group and its internal factional machinations, rather than outwards towards the needs of community leadership and governance (Copus, 2004).

However, as perceived by Friend and Jessop (1971), the test of 'improvement' can only be an empirical and to some extent a political one; whatever change is proposed in existing mechanisms of choice, it must be such as to gain acceptance in practice, by convincing a sufficient number of people that it offers them a better instrument for achieving the things they want to achieve.

\subsection{A New Proposed Model of Decision-Making Process}

The new proposed model of decision-making process at local government level is base on 13 factors that influence any decisions make by Councillors in regards to council's affairs. The rational of having this option is to assists Councillors in making a right, efficient and effective decisions by considering all those factors, collectively and comprehensively. The six main factors, as described earlier, will give a different weight on the importance of each factor. In conjunction to the recommendation of becoming advocate Councillors, they need to be alert to the characteristics and needs of the people they serve, and, where inequalities exist, Councillors need to help ensure that they are well addressed.

The application of the model begins at the pre-council meeting. The pre-council meeting should providing a forum for the debate of particular controversial issues at the stage before a formal committee decision was reached, either at the Committee Meeting or Full-Council Meeting. Base on the 13 factors, a consensus result or a firmly stand could be finalized, after considering the few alternatives or possibilities as propose by the member of the party. All members (Councillors) of political party should voice out their views and there was always a strong possibility that, meeting in a politically charged atmosphere and deprived of the guidance of their professional advisers, the members might find themselves becoming committed to resolutions, as perceived by Friend and Jessop (1971).

The Committee Meeting is an official occasion at which Councillors and officers meet together, listen to the issues and recommendations from the officers, before translated into official decisions. Where the more strategic decisions were concerned, Councillors seemed unable to address itself successfully to the task of making a 
balanced selection between alternatives. This tendency could be avoided by having a clear assessment on any particular contentious matters, based on 13 factors, as what have been debate and agreed at the pre-council meeting.

At the third level of decision-making process, all Councillors of the parties met as a group prior to the monthly Full-Council Meeting. The task is to screen the minutes of the various committees, and also to formulate their tactics for any other items to be dealt with on the council agenda (Friend and Jessop, 1971). The process will be much easier if the alternative and consensus have been develop and agreed at the first and the second level of the council's meeting, as what have been proposed under this new model. If the Full-Council Meeting unable to resolve any matters arises, or failed of having consensus results, then that particular minute is formally referred back to the Committee Meeting for further consideration and evaluation. The process of decision-making will goes through the same consequences process until the final and consensus results endorsed in the next Full-Council Meeting.

\section{Conclusion}

The complexity of the decision-making process at local government level always causes the difficulties for Councillors to make a rightful, objectively and effectively decisions. The existing model of decision-making did not provide them with a clear set of factors that guided them while debating any issues at the council meeting, and as a result, to some extent, we saw an inevitable outcome of the contrast between the complexity of choice and the limited options for acceptance or rejection of recommendations permitted by conventional committee procedures. Therefore the study, based on the theoretical conceptual of decision-making process, successfully develop a set of decision-guideline consisting of 13 factors to be used by Councillors while dealing with decision-making process. The six main preference factors choose by Councillors will definitely express the re-definition of their roles as Councillors in a more proper and acceptable sense.

\section{References}

Copus, C. (2004). Party Politics and Local Government. Great Britain, Manchester University Press.

Cox, H., \& Morgan, D. (1973). City Politics and the Press. Cambridge: Cambridge University Press.

Edwards, G. C. (1980). Implementing Public Policy. Washington D.C., Congressional Quarterly Press.

Friend, J.K., \& Jessop, W. N. (1971). Local Government and Strategic Choice-An Operational Research Approach to the Processes of Public Planning. London: Tavistock Publications.

Goh, B.L. (2008). Local plans. The Sun. Retrieved 12 February, from http://www.sun2surf.com

Hampton, W. (1970). Democracy and Community. London, Oxford University Press.

Heclo, H. (1969). The Councillor's Job. Public Administration, 47(2), 185-202. http://dx.doi.org/10.1111/j.1467-9299.1969.tb01146.x

Higgins, J., Deakin, N., \& Wicks, M. (1983). Government and Urban Poverty. Basil: Blackwell.

Jeffrey D. Greene. (2005). Public Administration in the New Century: A Concise Introduction.

Jones, G.W. (1973). The Functions and Organisation of Councillors. Public Administration, 51(2), 135-146. http://dx.doi.org/10.1111/j.1467-9299.1973.tb00133.x

Nikmatul Adha Nordin. (2011). Public participation in planning: a case study of Subang Jaya. USM Doctor of Philosophy, Penang.

Peter Self. (1972). Administrative Theories and Politics. London: George Allen \& Unwin Ltd.

Robert B.Denhardt, \& Janet V. Denhardt. (2006). Public Administration-An Action Orientation. U.S.: Thomson Wadsworth.

Sharpe, L.J. (1979). Decentralist Trends in Western Democracies. London, Sage.

William C. Johnson. (1996). Public Administration Policy, Politics and Practice. U.S.: Brown \& Benchmark.

Young, K., \& N. Rao. (1994). Coming to Terms with Change? The Local Government Councillor in 1993. York: Joseph Rowntree Foundation.

Young, K., \& N. Rao. (1995). Faith in Local Democracy. In J. Curtice, R. Jowell, L. Brook \& A. Park (Eds), British Social Attitudes: The Twelth Report (p.109). Aldershot: Dartmouth. 